\title{
FEEDING IN ADULT ARGULUS JAPONICUS THIELE, 1900 (MAXILLOPODA, BRANCHIURA), AN ECTOPARASITE ON FISH
}

BY

\author{
PETER D. WALKER ${ }^{1,3,4}$ ), IAIN J. RUSSON ${ }^{1}$ ), CHRISTOPHE HAOND ${ }^{1}$ ), \\ GERARD VAN DER VELDE ${ }^{1,2}$ ) and SJOERD E. WENDELAAR-BONGA ${ }^{1}$ )
}

1) Radboud University Nijmegen, Institute for Water and Wetland Research, Department of Animal Ecology and Ecophysiology, Heyendaalseweg 135, NL-6525 AJ Nijmegen, The Netherlands

2 ) Netherlands Centre for Biodiversity Naturalis, P.O. Box 9517, NL-2300 RA Leiden,

The Netherlands

3) APEM Aquatic Scientists Ltd., Centre for Innovation \& Enterprise, Begbroke Science Park, Sandy Lane, Yarnton, Oxfordshire OX5 1PF, U.K.

\begin{abstract}
The argulids are an economically important group of crustacean ectoparasites known to be problematic in fish farming operations from both temperate and tropical regions. Argulus japonicus was first described from Japanese fish but is now well established in many parts of the world including Europe. To aid the development of effective chemotheraputants and/or vaccines against these parasites it is essential to know exactly what these animals ingest when feeding upon their fish hosts. From past morphological studies authors have shown that these parasites use a proboscis-like mouth tube for feeding, however, until now there has been much speculation amongst authors over the diet of these animals. Live observations, histology, as well as scanning and transmission electron microscopy were used to examine the feeding apparatus and gut contents of individual larval and adult lice before and after feeding on juvenile common carp, Cyprinus carpio. Red coloration of the parasites gut after feeding was obvious, suggesting ingestion of red blood cells by the adult lice. Sections of the adult lice used for histology and TEM revealed red blood cells from the fish host within the parasites gut. Larval lice were found not to feed on blood cells because of their mouth part morphology and the lack of blood cells in their intestines. Haemorrhagic responses of the hosts skin by infection of adult lice was observed between 24 and $48 \mathrm{hrs}$ post infection. All techniques provided evidence that the adult parasites are indeed obligate blood feeders.
\end{abstract}

\section{RÉSUMÉ}

Les argulidés sont un groupe de crustacés ectoparasites, économiquement importants, connus pour poser des problèmes en aquaculture à la fois dans les régions tempérées et tropicales. Argulus japonicus a été décrit pour la première fois sur des poissons japonais, mais est maintenant bien établi dans de nombreuses parties du monde Europe comprise. Pour aider le développement d'une

${ }^{4}$ ) Author for correspondence; Fax: +44.(0)1865854801; e-mail: p.walker@apemltd.co.uk 
chimiothérapie effective et/ou de vaccins contre ces parasites, il est essentiel de connaître exactement ce que ces animaux ingèrent lorsqu'ils se nourrissent sur le poisson hôte. Des études morphologiques antérieures ont montré que ces parasites utilisent un tube buccal en sorte de proboscis pour s'alimenter. Cependant, jusqu'à présent, il y a eu de nombreuses spéculations entre les auteurs à propos de leur régime alimentaire. Des observations sur le vivant, de l'histologie ainsi que de la microscopie électronique par transmission et balayage ont été utilisées pour examiner l'appareil buccal et le contenu stomacal des individus larvaires et adultes avant et après un repas sur des juvéniles de carpe commune Cyprinus carpio. Une coloration rouge du tube digestif des parasites après alimentation a été observée, suggérant une ingestion de globules rouges par le pou adulte. L'observation histologique et par MET de coupes de poux adultes montrent la présence de globules rouges provenant du poisson hôte dans le tube digestif du parasite. Les poux larvaires ne se nourrissent pas de cellules sanguines de part leur morphologie buccale et de l'absence de cellules sanguines dans leur intestin. Des réponses hémorragiques au niveau de la peau de l'hôte infecté par des poux adultes ont été observées 24 à 48 h après l'infection. Toutes les techniques démontrent que les parasites adultes sont des hématophages obligatoires.

\section{INTRODUCTION}

Ectoparasitc lice from the genus Argulus have negative impacts on the stock of fish farms and recreational fisheries (Menezes et al., 1990; Northcott, 1997; Taylor et al., 2006). Therefore these parasites have received considerable attention from researchers during the last few decades (Walker et al., 2004). In spite of this attention it is difficult to find clear statements regarding the feeding mechanisms and diet of these parasites (Kearn, 2004).

The feeding apparatus of Argulus japonicus Thiele, 1900 and other argulid species have been relatively well described previously (Martin, 1932; Gresty et al., 1993; Kearn, 2004; Walker et al., 2004; Tam \& Avenant-Oldewage, 2006). The mouth tube is composed of a labium and labrum, which surround the buccal cavity. Contained within the buccal cavity are the mandibles and labial spines. In addition to the mouth tube there is a pre-oral stylet, which has been the topic of some debate for several decades. To date the function of this unique organ is still unclear but the general consensus is that it is used to deliver a toxin that may help to break down the epithelial cells of the host or induce haemorrhaging. Similarly, the function of the labial spines is as yet unknown.

There is much controversy in the literature over the diet of Argulus spp. Authors state that Argulus spp. feed on fish mucus (LaMarre \& Cochrane, 1992), skin (Van der Salm et al., 2000), externally digested cell contents (Lester \& Roubal, 1995), or tissue fluids (Frabioni, 1974). Others state that these animals are in fact obligate blood feeders (Van Duijn, 1956; Ahne, 1985; Poulin \& Fitzgerald, 1988; Mikheev et al., 1998, 2000; Pasternak et al., 2000), but even here some authors have argued that they only ingest blood serum and not whole blood (Ivanfi, 1926, referred to in Gresty et al., 1993). This controversy is not altogether surprising because there 
has been a distinct lack of detailed studies to show exactly what these animals are feeding upon.

The aim of this study was to provide evidence on the diet of A. japonicus. Live observations, histology, SEM, and TEM were used to examine the feeding apparatus and gut contents of $A$. japonicus after they had fed on juvenile common carp (Cyprinus carpio L., 1758). Results are discussed in relation to the importance of parasitic feeding mechanisms and diet for the development of effective control methods.

\section{MATERIAL AND METHODS}

Lice feeding experiment

Adult Argulus japonicus were collected from Nijmegen laboratory brood stock carp using blunt forceps. These lice were then held in a small beaker containing aquarium water for 48 hours at $20^{\circ} \mathrm{C}$, without access to a host. The water was replaced once after 24 hours. Several lice were then taken and allowed to feed on a juvenile carp (Cyprinus carpio) for 2 hours before once again being removed with a set of blunt forceps. Several fish were left with lice attached and examined at 24 and 48 hours post infection for gross pathological signs associated with parasitic infection. Live observations were then conducted by placing several fed and unfed parasites on microscope slides in a drop of water. The slide was placed in a freezer $\left(-20^{\circ} \mathrm{C}\right)$ for approximately 1 minute to reduce the level of activity exhibited by the animals whilst taking care not to allow freezing of the specimens to occur. Low power micrographs were obtained using a stereo microscope with a mounted digital camera.

\section{Histology of the parasite}

Lice were collected after feeding on juvenile common carp for 2 hours and immediately placed in Bouin's fixative. Samples were then processed for paraffin histology using the standard procedure. Paraffin sections were stained with Masson trichrome (Martoja \& Martoja, 1967).

\section{Scanning electron microscopy (SEM)}

Adult and larval lice were collected from Nijmegen brood stock carp and then immediately fixed in $2 \%$ glutaraldehyde in $0.1 \mathrm{M}$ cacodylate buffer and left overnight. Samples were then post-fixed for $2 \mathrm{~h}$ in ice cold $1 \% \mathrm{OsO}_{4}, 0.15$ $\mathrm{M}$ sucrose in the same buffer before being dehydrated through a graded ethanol series, critical point dried, and sputter coated with a microlayer of gold palladium. Specimens were observed with a JEOL SEM 6330. 


\section{Transmission electron microscopy (TEM)}

For electron microscopy, lice were collected after feeding for 2 hours on juvenile common carp. The lice were then dissected in $2 \%$ glutaraldehyde in 0.1 $\mathrm{M}$ cacodylate buffer and kept for $4 \mathrm{hrs}$ in ice cold fixative. After washing in $0.2 \mathrm{M}$ sucrose in $0.1 \mathrm{M}$ cacodylate buffer, dissected pieces of the shield were post-fixed for $2 \mathrm{~h}$ in $1 \% \mathrm{OsO}_{4}, 0.15 \mathrm{M}$ sucrose in the same buffer, washed in demineralized water, dehydrated in ethanol baths, and embedded in LR White resin. Ultra thin sections were cut using a diamond knife (Diatom), contrasted with uranyl acetate and lead citrate, and examined with a JEOL CXII transmission electron microscope.

\section{Histology of the host}

Skin samples were dissected from euthanized (overdose of anesthetic followed by spinal transaction) juvenile common carp (C. carpio) and immediately fixed in Bouins fixative for a minimum of 24 hours. Samples were subsequently dehydrated through a graded ethanol series and embedded in paraffin. Sections of $5 \mu \mathrm{m}$ were mounted on gelatinized glass slides and dried overnight at $40^{\circ} \mathrm{C}$. Slides were then stained with hematoxylin and eosine and examined microscopically.

\section{RESULTS}

Comparison of the feeding apparatus of larval and juvenile Argulus japonicus shows that the mouthparts are essentially comprised of the same component parts, e.g., mandibles, labrum, labium (fig. 1A, B). The most notable difference between the feeding apparatus of adult and larval lice is in the overall size of the mouthparts. In particular the aperture of the buccal cavity is substantially larger in adult lice (approx. $20 \mu \mathrm{m}$ across) than in larval lice (approximately $9 \mu \mathrm{m}$ across) (fig. 1A, B). The pre-oral stylet consists of a spine possessing a rounded tip behind which are located two small openings (fig. 1C). This stylet was either completely retracted inside its associated sheath, or partially exposed (fig. 1C) depending on the specimen.

Examination of live adult parasites using a stereo microscope revealed that after 48 hours without feeding the gut of these animals was completely empty (fig. 2A, B). The gut consists of a foregut or crop, and a hind gut (fig. 2). There are also many diverticula running through the dorsal carapace that begin from one of two lateral extensions of the crop, one on each side of the animal. Numerous chromatophores associated with the gut diverticula were also apparent (fig. 2). Just two hours after being allowed to attach and feed on a small juvenile common carp, many of the 

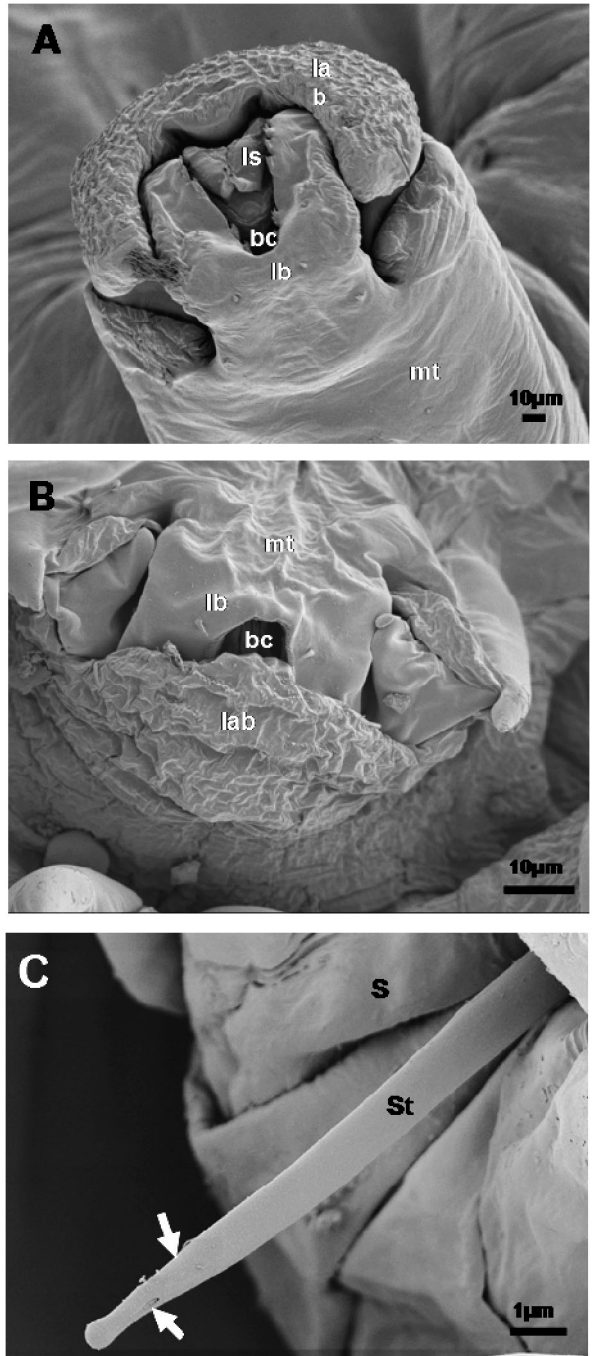

Fig. 1. Argulus japonicus Thiele, 1900, scanning electron micrographs of the mouthparts of: A, an adult; and, B, a larval specimen, showing the: mt, mouth tube; lab, labium; lb, labrum; ls, labial spine; and, bc, buccal cavity; $\mathrm{C}$, the pre-oral stylet takes the form of a hollow spine (St) possessing two openings near to its tip (white arrows) and is contained within a sheath (S) into which it can be retracted when not in use.

parasites exhibited a conspicuous red coloration within the various regions of the gut, suggesting that haematophagous activities had occurred and that the animals gut was now full of blood.

The anterior midgut and enteral diverticula of larval parasites examined $2 \mathrm{hrs}$ post hatch were seen to possess a red/brown coloured yolk (fig. 2F). This yolk was still present in all specimens examined 2 hrs after being allowed to attach 

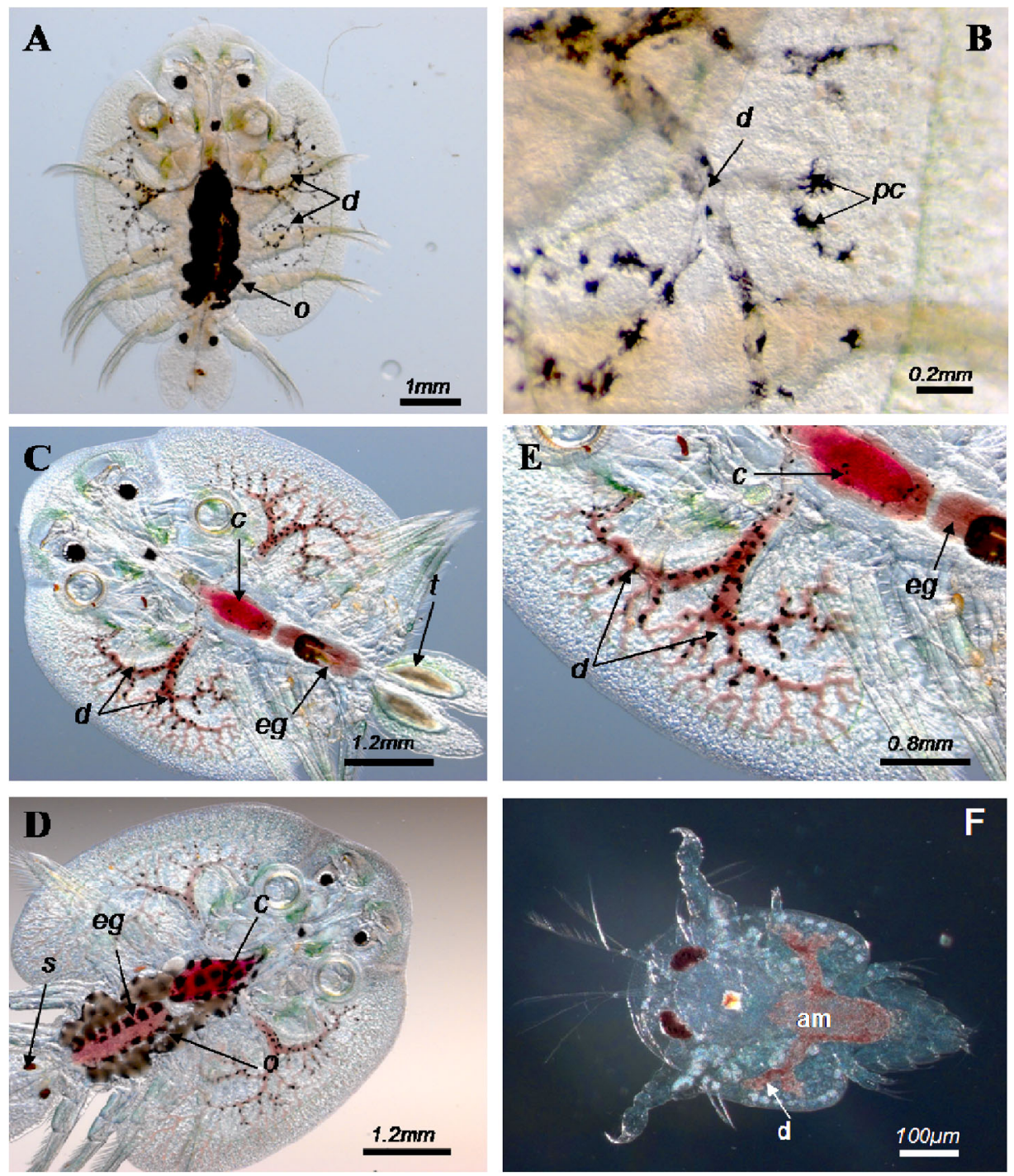

Fig. 2. Stereo micrographs of live Argulus japonicus Thiele, 1900: A-B, female specimen observed $48 \mathrm{hrs}$ after removal from its host: A, the ovaries are clearly visible as are the diverticula of the gut extending throughout the dorsal carapace; B, the empty diverticula can be seen along with associated pigment cells or chromatophores. C-E, male and female specimens removed from their host after feeding for two hours: $\mathrm{C}$, the male can be identified by the testes that are clearly visible within the abdominal lobes at the posterior end of the animal; $\mathrm{D}$, the female specimen is distinguished by the conspicuous ovaries and also by the spermathecae, which can be seen on the abdominal lobes; in both specimens blood can be seen in the foregut or crop, the diverticula of the gut, and in the end gut: E, magnified area of the male parasites dorsal carapace showing in detail the diverticula filled with blood; F, larval louse $2 \mathrm{hrs}$ post hatch: the anterior midgut and enteral diverticula (ed) can be seen to contain a red/brown yolk. Legends: c, foregut or crop; eg, hind/end gut; o, ovaries; t, testis; s, spemathecae; d, enteral diverticula; pc, pigment cells (chromatophores); am, anterior midgut. 
and feed on a small juvenile common carp. Squash preparations of larval parasites after having been attached to juvenile carp for $2 \mathrm{hrs}$ did not appear to contain carp erythrocytes.

Sections through various regions of a fed adult parasites body where gut diverticula are present show that the various gut parts contain substances assumed to be the parasites last meal. The TEM micrograph (fig. 3E) clearly shows the presence of nucleolated cells which could be identified as being erythrocytes from a fish.

Juvenile carp that had been infected for up to $48 \mathrm{hrs}$ exhibited prominent red lesions on their skin. These lesions appeared haemorrhagic and were often associated with attached parasites. Microscopical examination of these lesions revealed craters in the skin of the fish at the sites where parasites had been feeding. Infiltration of leukocytes into tissues surrounding the wounds was also observed (fig. 4).

\section{DISCUSSION}

Branchiuran lice have undergone major modifications of the mandibles and associated feeding appendages. Mandibles typically occur as a pair of transversely toothed hooks between the labium and labrum and this indeed is the case for specimens studied by us. These mandibles are located just inside the entrance to the buccal cavity forming part of the specialized proboscis (McLaughlin, 1982). The mechanism of feeding in argulids has also been described by several authors (e.g., Van Duijn, 1956; Kabata, 1985; Overstreet et al., 1993; Lester \& Roubal, 1995) but there is some controversy over the facts. Much of this controversy relates to the function of the pre-oral stylet, an organ unique to species of Argulus and Dipteropeltis. The authors here are of the opinion that adult argulids (and possibly juvenile lice) use the pre-oral, retractable stylet to inject toxic substances into their host creating a localized inflammatory response with subcutaneous haemorrhaging. Gresty et al. (1993) also demonstrated that this organ was used to inject substances into the host rather than to withdraw fluids as was believed by previous authors, e.g., Van Duijn (1956) and Kabata (1970). The parasite then likely uses its serrated mandibles, which can be everted, to tear a hole in the epidermal layers to gain access to the hosts' blood. Whole blood (including erythrocytes) is then sucked up through a proboscis-like mouth tube which, according to Kearn (2004), superficially resembles the mouth tube of a siphonostomatoid copepod.

Several authors have suggested that Argulus is haematophagous but Kabata (1970) stated that red blood cells have not been recorded in the gut of Argulus. 


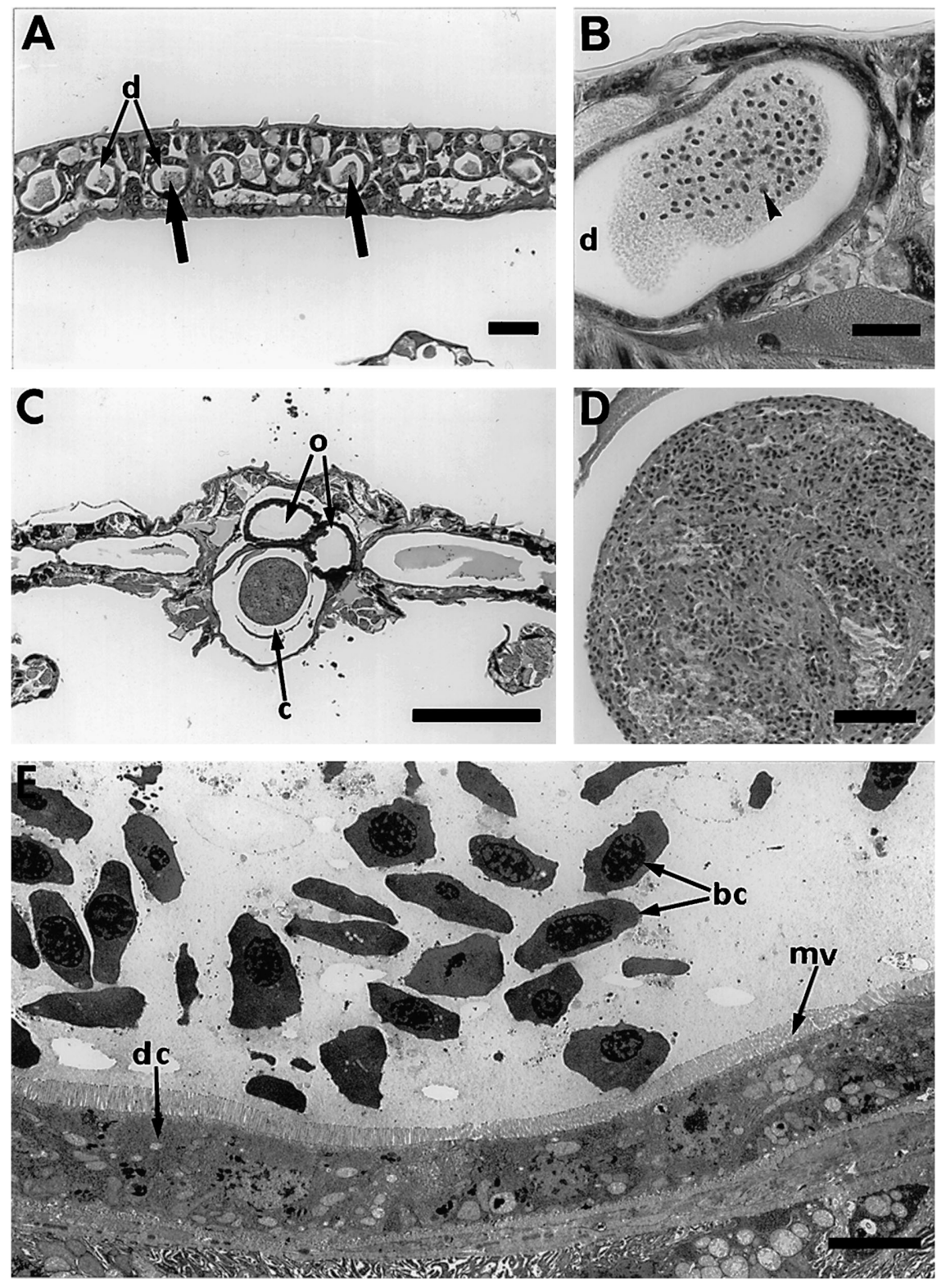

Fig. 3. Argulus japonicus Thiele, 1900: A, longitudinal section through the carapace; diverticula of the gut (d) seen in transverse section to contain clotted material (arrows); B, transverse section through a gut diverticulum (d), fish erythrocytes are clearly visible within the gut (arrowhead); C-D, transverse sections of the crop (c): C, ovaries (o) can be seen, clearly indicating the specimen was female, while the crop contains a pellet full of fish red blood cells, shown enlarged in (D); E, TEM micrograph of a transverse section through the gut diverticulum: digestive cells (dc) and microvilli (mv) surrounding the gut are clearly visible and fish red blood cells (bc) are clearly identifiable within the gut. Scale bars: A, $100 \mu \mathrm{m}$; B, $50 \mu \mathrm{m}$; C, $500 \mu \mathrm{m}$; D, $50 \mu \mathrm{m}$; E, $5 \mu \mathrm{m}$. 

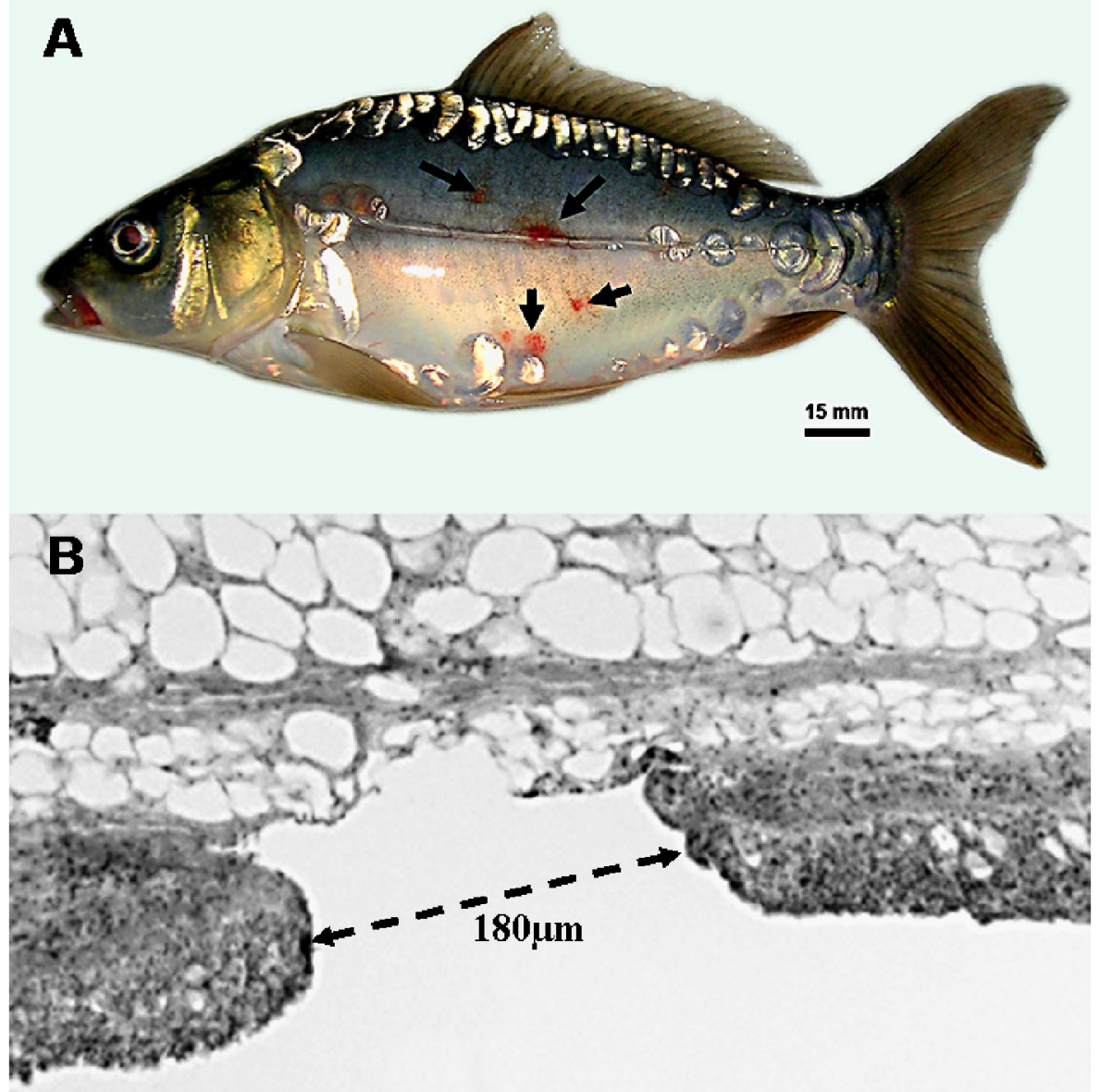

Fig. 4. A, juvenile common carp (Cyprinus carpio L., 1758) specimen 48 hrs after infection with adult Argulus japonicus Thiele, 1900, with arrows indicating haemorrhagic lesions caused by feeding activities of the parasites; $\mathrm{B}$, a section through the skin of another juvenile common carp, showing the crater-like wound inflicted by a feeding argulid (arrow).

Our observations revealed the presence of large numbers of nucleated erythrocytes in the gut of adult $A$. japonicus just 2 hrs after feeding, and strongly indicates that whole blood forms a significant part of the diet of these parasites. The extensively branched nature of the gut in Argulus spp. is comparable to that of leeches, which are also designed to take up masses of blood (Wesenberg-Lund, 1939). Whilst the precise function of the labial spines and pre-oral stylet has not been elucidated by this study we anticipate that future studies will demonstrate the presence of an anticoagulant aiding the haematophagous habits of A. japonicus. Certainly previous authors have described glands associated with pre-oral stylet 
and mouthparts (Wilson, 1903; Wesenberg-Lund, 1939; Gresty et al., 1993; Kearn, 2004).

However, in the case of larval A. japonicus the ingestion of whole blood (including erythrocytes) is unlikely. Erythrocytes from carp are typically around 12-13 $\mu \mathrm{m}$ in diameter (Imagawa et al., 1989). Our observations regarding the aperture size of the opening to the parasites buccal cavity demonstrate that it is not wide enough to allow the ingestion of whole red blood cells. In addition, no erythrocytes were observed in squash preparations of larval parasites. According to Tam \& Avenant-Oldewage (2006) the sizes of the proboscis (approximately $50 \mu \mathrm{m}$ ) and mandibular blades (approximately $15 \mu \mathrm{m}$ ) of a larval A. japonicus, located inside the proboscis are probably insufficient to penetrate down to the blood vessels located in the dermis of a typical cyprinid host due to the thickness of its epidermis (approximately $100 \mu \mathrm{m}$ ). This probably accounts for the absence of erythrocytes in larval A. japonicus (cf. Tam \& Avenant-Oldewage, 2006).

Shimura \& Inoue (1984) injected an extract derived from A. coregoni Thorell, 1864, into rainbow trout (Oncorhynchus mykiss Walbaum, 1792), and found that it induced a haemorrhagic response, which would facilitate haematophagy by $A$. coregoni. Forlenza et al. (2008) demonstrated an inflammatory response in carp skin following infection with $A$. japonicus. A similar haemorrhagic response was observed in carp in this study between 24 and 48 hours post infection suggesting that, like its relative A. coregoni, A. japonicus utilizes chemical secretions to facilitate feeding.

Blood feeding parasites have long been a topic of interest in many biological sub-disciplines from the medical sciences to animal physiology and ecology. The reasons for studying animals that show this feeding behaviour are diverse and range from improvements in understanding the importance of haematophagous animals as vectors for important diseases of farmed animals and humans (e.g., SVCV, Ahne, 1985; malaria, Prévot et al., 2003; Lyme disease, Randolph, 1998) to the understanding of the role of these animals within ecosystems, e.g., host population control. Kabata (1985) stated that aquaculturists should pay particular attention to the control of blood sucking parasites due to their potential as vectors for other serious pathogens (e.g., spring viraemia of carp virus, infectious pancreatic necrosis, bacterial haemorrhagic septicaemia). A. japonicus can now be confirmed as being within this important group of 'blood-suckers' and it is believed by the authors that other argulids will also be confirmed as blood feeders in the future. However, Covich \& Thorp (2001) suggest that blood feeding is likely to be speciesspecific for branchiurans. 


\section{ACKNOWLEDGEMENTS}

The authors gratefully acknowledge T. Spanings for his assistance with fish husbandry and maintenance of the parasite stocks. P. D. Walker and I. J. Russon acknowledge the financial support provided through the European Community's Improving Human Potential Programme under contract (HPRN-CT-2001_00214), (PARITY).

\section{REFERENCES}

Ahne, W., 1985. Argulus foliaceus L. and Piscicola geometra L. as mechanical vectors of spring viraemia of carp virus (SVCV). Journ. Fish Dis., 8: 241-242.

Covich, A. P. \& J. H. ThORP, 2001. Introduction to the subphylum Crustacea. In: J. H. THORP \& A. P. Covich (eds.), Ecology and classification of North American freshwater invertebrates ( $2^{\text {nd }}$ ed.): 777-809. (Academic Press, San Diego, California).

Forlenza, M., P. D. Walker, B. J. De Vries, S. E. Wendelaar Bonga \& G. F. WIEGERTJES, 2008. Transcriptional analysis of the common carp (Cyprinus carpio L.) immune response to the fish louse Argulus japonicus Thiele (Crustacea: Branchiura). Fish Shellfish Immunol., 25: 76-83.

FRABOni, J., 1974. Argulus: the carp louse; life history of the parasite Argulus; fish symptoms; disease prevention and treatment. The American Currents, 2 (1): 9-10.

Gresty, K., G. A. Boxshall \& K. Nagasawa, 1993. The fine structure and function of the cephalic appendages of the branchiuran parasite, Argulus japonicus Thiele. Philos. Trans. Roy. Soc., London, (B) 339: 119-135.

Imagawa, T., Y. Hashioto, H. Kitagawa, Y. Kon, N. Kudo \& M. Sugimura, 1989. Morphology of blood cells in carp (Cyprinus carpio L.). Japanese Journ. vet. Sci., 6: 11631172.

IVANFI, E., 1926. A pontytetu (Argulus foliaceus L.) morphologiaja es biologiaja. Arch. Balaton, Budapest, 1: 145-163.

KabatA, Z., 1979. Crustacea as enemies of fishes. In: S. F. SNIESZKo \& H. R. Axelrod (eds.), Diseases of fishes, 1: 1-171. (T.F.H. Publications, Jersey City, New Jersey).

— - 1985. Parasites and diseases of fish cultured in the tropics: 1-318. (Taylor \& Francis, London).

KEARN, G. C., 2004. Leeches, lice and lampreys: a natural history of skin and gill parasites of fishes: 1-432. (Springer, Dordrecht).

LAMARre, E. \& P. A. Cochrane, 1992. Lack of host species selection by the exotic ectoparasitic crustacean, Argulus japonicus. Journ. Freshwat. Ecol., 7: 77-80.

Lester, R. J. G. \& F. R. Roubal, 1995. In: P. Woo, Fish diseases and disorders, 1: protozoan and metazoan infections: 475-598. (CAB International, Wallingford).

Martin, F. M., 1932. On the morphology and classification of Argulus (Crustacea). Proc. zool. Soc. London, 103: 771-806.

Martoja, R. \& M. MartojA, 1967. Initiation aux techniques de l'histologie animale: 1-345. (Masson et Cie, Paris).

McLaughlin, P. A., 1982. Comparative morphology of crustacean appendages. In: L. G. ABELE (ed.), The biology of Crustacea, 2: 197-256. (Academic Press, New York).

Menezes, J., M. A. Ramos, T. G. Pereira \& A. Moreira Da Silva, 1990. Rainbow trout culture failure in a small lake as a result of massive parasitosis related to careless introductions. Aquaculture, 89: 123-126. 
Mikheev, V. N., A. V. Mikheev, A. F. Pasternak \& E. T. Valtonen, 2000. Light-mediated host searching strategies in a fish ectoparasite, Argulus foliaceus L. (Crustacea: Branchiura). Parasitology, 120: 409-416.

MikheEV, V. N., E. T. VAltonEn \& P. Rintämaki-Kinnunen, 1998. Host searching in Argulus foliaceus L. (Crustacea: Branchiura): the role of vision and selectivity. Parasitology, 116: 425430.

NorthcotT, S. J., 1997. An outbreak of freshwater fish lice, Argulus foliaceus L., seriously affecting a Scottish stillwater fishery. Fisheries Manag. Ecol., 4: 73-75.

Overstreet, R. M., I. Dy Kova \& E. HAWKInS, 1993. Branchiura. In: F. W. HARrison \& A. G. Humes (eds.), Microscopical anatomy of the invertebrates, 9, Crustacea: 384-413 (Wiley Liss Inc., New York).

Pasternak, A. F., V. N. Mikheev \& E. T. Valtonen, 2000. Life history characteristics of Argulus foliaceus L. (Crustacea: Branchiura) populations in central Finland. Ann. Zool. Fennici, 37: 25-35.

Poulin, R. \& G. J. FitzGerald, 1988. Water temperature, vertical distribution, and risk of ectoparasitism in juvenile sticklebacks. Canadian Journ. Zool., 66: 2002-2005.

Prévot, G. I., C. LAurent-Winter, F. Rodhain \& C. Bourgouin, 2003. Sex-specific and blood meal-induced proteins of Anopheles gambiae midguts: analysis by two-dimensional gel electrophoresis. Malaria Journ., 2 (1) doi:10.1186/1475-2875-2-1.

RANDOLPH, S. E., 1998. Ticks are not insects: consequences of contrasting vector biology for transmission potential. Parasitol. Today, 14: 186-192.

Shimura, S. \& K. InOUe, 1984. Toxic effects of extract from the mouth-parts of Argulus coregoni Thorell (Crustacea: Branchiura). Bull. Japanese Soc. scient. Fish., 50: 729.

Tam, Q. \& A. Avenant-Oldewage, 2006. The digestive system of larval Argulus japonicus (Branchiura). Journ. Crustacean Biol., 26: 447-454.

Taylor, N. G. H., C. Sommerville \& R. Wooten, 2006. The epidemiology of Argulus spp. (Crustacea: Branchiura) infections in Stillwater trout fisheries. Journ. Fish Dis., 29: 193-200.

VAn Der Salm, A. L., D. T. Nolan, F. A. T. Spanings \& S. E. WendelaAr Bonga, 2000. Effects of infection with the ectoparasite Argulus japonicus (Thiele) and administration of cortisol on cellular proliferation and apoptosis in the epidermis of common carp, Cyprinus carpio L., skin. Journ. Fish Dis., 23: 173-184.

VAN DUIJN, C., 1956. Diseases of fishes: 1-309. (Water Life, London).

WAlKer, P. D., G. Flik \& S. E. WendelaAR BongA, 2004. The biology of parasites from the genus Argulus and a review of the interactions with its host. Symposia for the Society of Experimental Biology, 55: 107-129.

Wesenberg-Lund, C., 1982. Biologie der Süsswassertiere: wirbellose Tiere: 1-772. (Strauss \& Cramer, Hirschberg, Germany).

WiLson, C. B., 1903. North American parasitic copepods of the family Argulidae, with a bibliograpghy of the group and a systematic review of all known species. Proceedings of the United States National Museum, 25: 635-742. 